\title{
Marcin Kałduński*
}

\section{SOME REFLECTIONS ON ARBITRATION IN THE YUKOS V. THE RUSSIAN FEDERATION CASE}

\begin{abstract}
In an extraordinary arbitration proceedings recently concluded, the Tribunal found that the respondent State breached its obligations under the Energy Charter Treaty and ordered Russia to pay damages in excess of USD 50 billion to the former Yukos shareholders. This article considers the application of the principle of clean hands in the Yukos v. The Russian Federation case. The arbitral Tribunal held that the said principle does not form a part of positive international law and therefore it was not applicable in the present dispute. The principal aim of the article is to critically analyze the arbitral Award concerning the principle of clean hands. Additionally, the contribution also discusses the costs of the Yukos arbitrations.
\end{abstract}

Keywords

principle of clean hands - costs of arbitration - Energy Charter Treaty

International Law Department; Nicolaus Copernicus University. 


\section{INTRODUCTION}

In the arbitration under the Energy Charter Treaty (ECT) Yukos shareholders have triumphed in a ten-year dispute with the Russian Federation. In a soon-to-be famous Award rendered on 18 July 2014, an Arbitral Tribunal sitting in The Hague under the auspices of the Permanent Court of Arbitration (PCA) held unanimously that the Russian Federation breached its international obligations under the ECT by expropriating Yukos Oil Company and, therefore, it ordered the Respondent to pay damages in excess of USD 50 billion to the former Yukos shareholders and USD 60 million of legal fees.

The Tribunal was chaired by Yves Fortier. The Russian Federation appointed Judge Stephen Schwebel, former President of the International Court of Justice, Chile. The Claimants appointed Dr. Charles Poncet.

The proceedings in the case were enormous arbitrations and, at the highest, the Claimants were claiming damages from the Respondent of "no less than US\$ 114174 billion"1. Since the beginning of the arbitrations, the Tribunal has held five procedural hearings with the Parties and issued 18 procedural orders. In 2008 the Tribunal held a ten-day hearing on jurisdiction and admissibility and, in November 2009, issued three Interim Awards, each over 200 pages. In 2012, a twenty-one day Hearing on the merits was attended by over fifty party representatives. The written submissions of the parties span more than 4000 pages and the transcripts of the hearings more than 2700 pages. Over 8800 exhibits have been filed with the Tribunal2.

The purpose of this contribution is to reflect on a certain aspect of the Awards, to wit, the application of the principle of clean hands by the Arbitral Tribunal. To this end, the article starts with the factual background of the case, while section 3 is devoted to the main issue

1 Hulley Enterprises Limited (Cyprus) v. The Russian Federation, UNCITRAL, PCA Case No. AA 226; Yukos Universal Limited (Isle of Man) v. The Russian Federation, UNCITRAL, PCA Case No. AA 227; Veteran Petroleum Limited (Cyprus) v. The Russian Federation, UNCITRAL, PCA Case No. AA 228; Final Awards of 18.07.2014, at para. 4 (hereinafter: Awards). The proceedings in the above cases were joined and decided by the same Tribunal, which delivered three virtually identical Awards in all three cases on the same day.

2 Ibidem, at para. 4. 
discussed in the article. Section 4 contains a brief summary on the costs of the Yukos case. A set of concluding remarks are contained in section 5 .

\section{FACTUAL BACKGROUND}

It is exceptionally difficult to summarize the facts of such a complex case in a few paragraphs, but an outline of the facts is necessary for the purpose of this contribution, in order to understand the reasoning of the Tribunal. At the beginning, it should be recalled that in 2003 Yukos was the largest oil company in Russia. It had around 100000 employees, six main refineries and a market capitalization of about USD 33 billion. The Russian Federation created the company in 1993 as part of a large-scale reorganization of the oil production and processing industry into vertically integrated oil companies. The shareholders of Yukos and, especially, Mr Khodorkovsky, fell into conflict with the Russian authorities, including the President of the Russian Federation, Mr Putin. The conflict concerned also the political issues, including the policy goals pursued by the Russian Federation and the support for political opposition to Mr Putin. The record of the arbitral case were also replete with evidence pertaining to the events underlying the so-called campaign of harassment and intimidation ${ }^{3}$. According to Claimants, Mr Khodorkovsky's participation in the social policy and political spheres in Russia, coupled with Yukos' growing economic power, came to be perceived as a threat by the Russian authorities. The turning point was to be a meeting at the Kremlin between President Putin and the Russian Union of Industrialists end Entrepreneurs on 19 February 2003, at which Mr. Khodorkovsky delivered a speech about corruption in Russia which was negatively received by the President 4 . From June 2003, the Office of the Prosecutor General launched a series of investigations against various members of Yukos' management, including Mr. Khodorkovsky. The authorities seized key documents of the company creating difficulties in managing Yukos and preparing the annual financial statements. Mr Khodorkovsky was arrested at gunpoint on 25 October 2003 and convicted of theft and tax evasion

3 Ibidem, at paras. 794, 813.

4 Ibidem, at paras. 766-768, 783-784, 788. 
in 2005. The Tribunal found that the investigation had been carried out with excessive harshness 5 . The Respondent's aggressive campaign against Yukos impacted significantly on the management of the company. The intimidation and harassment disrupted the operations of Yukos and contributed to its demise ${ }^{6}$.

The Russian authorities considered the conduct of Yukos to be tax abuse or tax evasion as they were questioning the legality of Yukos' tax optimization scheme ${ }^{7}$. In the Tribunal's view, the Russian tax authorities used the "re-attribution" formula not only so as to be able to collect the revenue-based taxes against Yukos, but also so as to establish a basis for imposing on Yukos the massive VAT liability and excessive fines that followed. The overall amount of re-assessed tax liabilities imposed upon Yukos by the Russian Federation, including interest and fines, amounted to USD 10,589 billion $^{8}$. While Yukos was vulnerable on some aspects of its tax optimization scheme, principally because of the sham-like nature of certain elements of its operations in at least some of the low-tax regions, and could have faced some legitimate claims relating to revenuebased taxes had the Russian Federation limited itself to bona fide taxation measures, the State apparatus decided to take advantage of that vulnerability; it did so by launching a full assault on Yukos and its beneficial owners in order to bankrupt Yukos and appropriate its assets while, at the same time, removing Mr. Khodorkovsky from the political arena $^{9}$. In 2004 the core asset of Yukos, YNG (Yuganskneftegaz, Yukos' core production subsidiary) was auctioned ${ }^{10}$. The auction took place on 19 December 200411. The asset of YNG was acquired by Rosneft, a state-owned company, through an intermediary, Baikal ${ }^{12}$. The latter firm was obviously a vehicle created solely for the purpose of bidding

\footnotetext{
5 Ibidem, at para. 811.

6 Ibidem, at paras. 819-820. regions to mitigate tax burdens.

8 Ibidem, at para. 581.

9 Ibidem, at para. 1404.

10 Ibidem, at paras. 981,988

11 Ibidem, at para. 1003.

12 Ibidem, at paras. 1004-1006.
}

7 See: ibidem, at paras. 272-502. Very shortly, the tax optimization scheme was employed by Russian oil companies in a similar fashion. The key features of their operations were firstly: vertical integration; secondly transfer pricing; and thirdly the use of low-tax 
at the auction ${ }^{13}$. The price of US 9,35 billion paid at the auction for the 76,79 shares of Yukos in YNG was far below the fair value of those shares $^{14}$. Therefore, the auction was rigged ${ }^{15}$. In the Tribunal's view, the auction was not driven by motives of tax collection but by the desire of the State to acquire Yukos' most valuable asset and bankrupt Yukos. It was in effect a devious and calculated expropriation ${ }^{16}$. As the European Court of Human Rights pointed out, the choice of YNG as the first Yukos asset to be auctioned to satisfy Yukos' tax debts was "capable of dealing a fatal blow to its ability to survive the tax claims and to continue its existence"17. Subsequently, the Moscow Arbitrazh Court announced bankruptcy on 4 August 2006 and the company was struck off from the registry on 21 November 200718. The Tribunal held that the totality of the bankruptcy proceedings had not been part of a process for the collection of taxes, but rather indeed the final act of the destruction of the company by the Russian Federation and the expropriation of its assets for the sole benefit of the Russian State and State-owned companies Rosneft and Gazprom ${ }^{19}$.

The Tribunal concluded that "the primary objective of the Russian Federation was not to collect taxes but rather to bankrupt Yukos and appropriate its valuable assets"20. The PCA Tribunal held that the Russian Federation expropriated the Claimants' investment in violation of Article 13 of the ECT ${ }^{21}$. Moreover, the Russian Federation breached

\footnotetext{
13 Ibidem, at para. 1024.

14 Ibidem, at para. 1020

15 Ibidem, at para. 1036. See: RosInvestCo UK Ltd. v. The Russian Federation, SCC Case No. V079/2005, Final Award of 12.09.2010, at para. 620(d); Quasar de Valors SICAV S.A., Orgor de Valores SICAV S.A., GBI 9000 SICAV S.A. v. The Russian Federation, SCC No. 24/2007, Award of 20.07.2012, at para. 110.

16 Award, at para. 1037.

17 OAO Neftyanaya Kompaniya Yukos v. Russia, Application no. 14902/04, Judgment of 20.09.2011, at para. 653. See: Award, at para. 1043.

18 Ibidem, at paras. 1045, 1069, 1090, 1099.

19 Ibidem, at para. 1180, quoting in part the statement of Claimants. See: RosInvestCo UK Ltd.

v. The Russian Federation, SCC Case No. V079/2005, Final Award of 12.09.2010, at para. 620(e); Quasar de Valors SICAV S.A., Orgor de Valores SICAV S.A., GBI 9000 SICAV S.A. v. The Russian Federation, SCC No. 24/2007, Award of 20.07.2012, at paras 141, 157-158.

20 Awards, at para. 756.

21 Ibidem, at paras. 1548-1549, 1580-1585.
} 
the fair and equitable treatment standard covered by Article 10(1) of the ECT 22, as well as the obligation not to impair by any unreasonable or discriminatory measures management, maintenance, use, enjoyment, or disposal of investment as required by Article 10(1) of the ECT ${ }^{23}$. The Tribunal awarded to the Claimants the total damages of USD 50,020,867,798 and the interest thereof ${ }^{24}$.

\section{Preliminary objections RAISED by the ReSPONDENT.}

\section{THE PRINCIPLE OF CLEAN HANDS}

\subsection{INTRODUCTION}

The Tribunal addressed three preliminary objections made by the Respondent in its Final Award. The first objection concerned the fork-in-the road provision embodied in Article 26(3)(b)(i) of the ECT; the second objection related to the "unclean hands" of the investor, and the last referred to the relevance of Article 21 of the ECT.

The Tribunal dismissed the objection based on Article 26(3)(b)(i) of the ECT ${ }^{25}$. It also rejected an objection based on the complex provision embodied in Article 21 of the ECT (a carve out clause from the ECT for "taxation measures" and a "claw back" for Article 13 of the ECT in relation to "taxes") ${ }^{26}$. The most interesting point was the submission by the Respondent that the Claimants had come to the Tribunal with unclean hands that resulted in "one or many of the following consequences: (a) the Tribunal does not have jurisdiction over Claimants' claims; (b) Claimants' claims are inadmissible; and/or (c) Claimants should be deprived of the substantive protections of the ECT" 27 . Since the principle of clean hands has been extensively discussed in investment jurisprudence and forms a subject of controversy among arbitrators and scholars,

\footnotetext{
Ibidem, at paras. 1511-1516.

Ibidem, at paras. 1519.

Ibidem, at para. 1827.

See: ibidem, at paras. $1256-1272$.

6 Ibidem, at paras. 1375-1447.

27 Ibidem, at para. 1273.
} 
it is worth focusing on this issue and reflecting upon the decision of the Arbitral Tribunal.

The principle of clean hands has been discussed by a number of investment tribunals. It has also been dealt with under the "investment made in accordance with law" clause ${ }^{28}$. None of the tribunals has expressly accepted the contention that the said principle forms a part of positive international law. Nonetheless, the Respondent alleged that the Claimants were an instrumentality of a "criminal enterprise". It listed 28 instances of alleged illegal and bad faith conduct by Claimants or attributable to Claimants involving a variety of actors and spanning over ten years, including (a) conduct related to the acquisition of Yukos and subsequent consolidation of control over Yukos and its subsidiaries (e.g. skimming

28 See, e.g.: Saluka Investments BV (The Netherlands) v. the Czech Republic, PCA, UNCITRAL, Partial Award of 17.03.2006, at para. 174; Inceysa Vallisoletana, S.L. v. Republic of El Salvador, Award of 2.08.2006, ICSID Case No. ARB/03/26, at paras. 230-252; World Duty Free Company Limited v. The Republic of Kenya, Award of 4.10.2006, ICSID Case No. ARB/00/7. See: Metal-Tech Ltd. v. Republic of Uzbekistan, Award of 4.10.2013, ICSID Case No. ARB/10/3, passim, and, especially, paras. 110 (iii), 373-373; Fraport AG Frankfurt Airport Services Worldwide v. Republic of the Philippines, Award of 16.08.2007, ICSID Case No. ARB/03/25, at paras. 397-404; Rumeli Telekom A.S. and Telsim Mobil Telekomunikasyon Hizmetleri A.S. v. Republic of Kazakhstan, Award of 29.07.2008, ICSID Case No. ARB/05/16, at paras. 235, 310, 320-322; Plama Consortium Limited v. Republic of Bulgaria, Award of 27.08.2008, ICSID Case No. ARB/03/24, at para. 138; Waguih Elie George Siag and Clorinda Vecchi v. The Arab Republic of Egypt, Award of 1.06.2009, ICSID Case No. ARB/05/15, at para. 163; Gustav F W Hamester GmbH \& Co KG v. Republic of Ghana, Award of 18.06.2010, ICSID Case No. ARB/07/24, at para. 123; Niko Resources (Bangladesh) Ltd. v. Bangladesh Petroleum Exploration \& Production Company Limited ("Bapex") and Bangladesh Oil Gas and Mineral Corporation, Decision on Jurisdiction of 19.08.2013, ICSID Case No. ARB/10/11, at paras. 477-483. See also: Salini Costruttori S.p.A. and Italstrade S.p.A. v. Kingdom of Morocco, Decision on Jurisdiction of 23.07.2001, ICSID Case No. ARB/00/4, at para. 45; Tokios Tokelés v. Ukraine, Decision on Jurisdiction of 29.04.2004, ICSID Case No. ARB/02/18, at para. 84; Desert Line Projects LLC v. The Republic of Yemen, Award of 6.02.2008, ICSID Case No. ARB/05/17, at para. 104; Phoenix Action Ltd. v. The Czech Republic, Award of 15.04.2009, ICSID Case No. ARB/06/5, at para. 101; Railroad Development Corporation v. Republic of Guatemala, Second Decision on Objections to Jurisdiction of 18.05.2010, ICSID Case No. ARB/07/23, at para. 146; Saba Fakes v. Republic of Turkey, Award of 14.07.2010, ICSID Case No. ARB/07/20, at para. 119; Alpha Projektholding GmbH v. Ukraine, Award of 8.11.2010, ICSID Case No. ARB/07/16, at paras. 298-302; SAUR International SA v. Republic of Argentina, Decision on Jurisdiction and Liability of 6.06.2012, ICSID Case No. ARB/04/4, at paras. 310-312; Quiborax S.A., Non Metallic Minerals S.A. and Allan Fosk Kaplún v. Plurinational State of Bolivia, Decision on Jurisdiction of 27.09.2012, ICSID Case No. ARB/06/2, at para. 266; Ambiente Ufficio S.p.A. and others v. Argentine Republic, Decision on Jurisdiction and Admissibility of 8.02.2013, ICSID Case No. ARB/08/9, at para. 517. 
profits of Yukos and its production subsidiaries for their own self-enrichment); (b) conduct related to the Cyprus-Russia Agreement for the Avoidance of Double Taxation with Respect to Taxes on Income and on Capital of 5 December 1998 (e.g. evading hundreds of millions of dollars in Russian taxes on profits from transactions in and profits from sales of Yukos shares); (c) conduct related to the tax optimization scheme (e.g. concealing Yukos' continued control of its trading shells by resorting to call options or other artifices and by fabricating corporate and other transactional documents); (d) action taken in hindrance of the enforcement of Russia's tax claims (e.g. concealing the share registers' of Yukos' subsidiaries to obstruct the bailiffs' enforcement of Yukos' tax obligations). The Claimants rejected all allegations underlining that the Respondent's claims amounted to nothing more than an attempt to shift blame for the actions of the Russian Federation to the Claimants ${ }^{29}$.

The Respondent's position was as follows. It submitted, consistently with international case law and the doctrine of international law, that the unclean hands of Claimants deprived the Tribunal of jurisdiction, and rendered the investment claims inadmissible and/or deprived the Claimants of the substantive protections of the ECT ${ }^{30}$. According to the Respondent, the ECT protects only bona fide and lawful investments and the Respondent's consent to arbitrate extends only to such investments. A treaty must be interpreted in good faith and in accordance with its object and purpose. Consequently, the Respondent argued that the object and purpose of the ECT does not include the promotion and protection of illegal investments. Rather, as stated in the Treaty's introductory note, "[t]he fundamental aim of the [ECT] is to strengthen the rule of law on energy issues". The Russian Federation further argued that, even in the absence of an express legality requirement clause in an investment treaty, to which belongs the ECT, illegal investments will not be protected ${ }^{31}$. The protection must be denied both in the case

\footnotetext{
29 Awards, at paras. 1275, 1278, 1281, 1283-1310.

30 Ibidem, at para. 1313.

31 The Respondent referred to Plama Consortium Limited v. Bulgaria, ICSID Case No. ARB/03/24, Award, 27.08.2008; Phoenix Action Ltd. v. Czech Republic, ICSID Case No. ARB/06/5, Award, 15.04.2009; SAUR International S.A. v. Argentina, ICSID Case No. ARB/04/4, Decision on Jurisdiction and Liability, 6.06.2012.
} 
of illegality in the making of an investment and in the case of its performance ${ }^{32}$.

What is more, the Respondent submitted that a claimant who is guilty of illegal conduct is deprived of the necessary ius standi to complain of corresponding illegalities by the State. This requirement of "clean hands", argued Respondent, is a "general principle of law" within the meaning of Article 38(1)(c) of the ICJ Statute. Respondent cited the ICJ's decision in the Case Concerning the Gabčikovo-Nagymaros Project ${ }^{33}$ and various dissenting opinions by ICJ judges, including the dissenting opinion of Judge Schwebel in the Case Concerning Military and Paramilitary Activities in and against Nicaragua ${ }^{34}$, as well as a number of decisions of mixed claims commissions rendered in cases of diplomatic protection ${ }^{35}$.

In response to the Claimant's contention that the Respondent was estopped from raising matters of which it had long been aware of, but had never challenged, the Respondent asserted that it was not estopped from invoking the Claimants' unclean hands in this arbitration by any failure to take prompt action. The Claimants failed to satisfy the legal standard for estoppel ${ }^{36}$. This standard, argued the Respondent, was confirmed by the ICJ in the North Sea case: "it appears to the Court that only the existence of a situation of estoppel could suffice to lend substance to this contention, - that is to say if the Federal Republic were now precluded from denying the applicability of the conventional regime, by reason of part conduct, declarations, etc., which not only clearly and consistently evinced acceptance of that regime, but also had caused

\footnotetext{
32 Awards, at paras. 1317-1319.

33 Gabčikovo-Nagymaros Project (Hungary/Slovakia), Judgment of 25.09.1997, I.C.J. Reports 1997, at para. 133. However, the Court mentioned only the principle ex iniuria ius non oritur and did not discuss, even indirectly, the principle of clean hands.

34 Dissenting opinion of Judge Schwebel, Military and Paramilitary Activities in and against Nicaragua (Nicaragua v. United States of America), Merits, Judgment of 27.06.1986, I.C.J. Reports 1986, at para. 268.

35 See: Awards, at para. 1315, note 1714.

36 Ibidem, at paras. 1322, 1338-1339. Claimants argued that acquiescence, or the silence or absence of protest in circumstances which generally call for a positive reaction signifying an objection, may in and of itself result in estoppel, where the other elements of estoppel are not made out. It relates especially to Respondents allegations with respect to the creation and original acquisition of Yukos 1995 and with respect to the alleged violation of Cyprus-Russia Agreement. The Respondent must have had knowledge of the alleged violations and did not take any actions.
} 
Denmark or the Netherlands, in reliance on such conduct, detrimentally to change position or suffer some prejudice. Of this there is no evidence whatever in the present case" 37 .

In the end, the Respondent added that informal or contra legem acceptance of an investment by the host State that is illegal under the host State's domestic law cannot provide a basis for estoppel ${ }^{38}$.

On their part, the Claimants rejected the Respondent's allegations and objected that their "unclean hands", even if proved by the Russian Federation, "could have no impact on their claims in these arbitrations because: (a) the ECT does not contain any principle of «unclean hands»; (b) no principle of «unclean hands» has been recognized as a general principle of law; and (c) the instances of «unclean hands» alleged by Respondent are «collateral illegalities» that do not fall within the parameters of any «unclean hands» doctrine" 39 . The Claimants underlined that the ECT remains silent with respect to the legality requirement and contains no such clause. Nonetheless, even when interpreting treaty provisions expressly requiring compliance with host State laws, investment tribunals have strictly construed such provisions. Moreover, the alleged illegalities must be related to the making of an investment or have an immediate and necessary relation to a claimant's cause of action. Therefore, none of Respondent's allegations are covered by any principle of clean hands ${ }^{40}$. Last but not least, the Claimants submitted that, even if the general principle of clean hands existed, it would not confer upon States the right to violate investors' rights ${ }^{41}$.

The Arbitral Tribunal ultimately rejected all of the Respondent's arguments. It started its consideration by recalling the text of the relevant Articles of the ECT and the VCLT essential to resolving the issue in question ${ }^{42}$. It noted that the ECT contains neither any express reference

\footnotetext{
37 North Sea Continental Shelf (Federal Republic of Germany/Netherlands) (Federal Republic of Germany/Denmark), Judgment of 20.02.1969, I.C.J. Reports 1969, at para. 30.

38 Awards, at para. 1325.

39 Ibidem, at para. 1326.

40 Ibidem, at paras. 1334-1336.

41 Ibidem, at para. 1340.

42 Ibidem, at paras. 1343-1344. Article 26(6) of the ECT provides that "[a] tribunal established under paragraph (4) shall decide the issues in dispute in accordance with this Treaty and
} 
to the principle of clean hands nor an express requirement that investments be made in accordance with the laws of the host State. Having in mind the need to interpret treaties in good faith and to take their object and purpose into consideration, the Tribunal opined that the ECT as a whole may be understood as conditioning the protection granted to investments on their legality, or on the good faith of the investor. It may also be the case that the principle of clean hands, as a general principle of law, could be relevant pursuant to Article 26(6) of the ECT which states that the Tribunal shall decide the present dispute in accordance with the Treaty and applicable rules and principles of international law ${ }^{43}$.

In order to decide on this preliminary objection, the arbitrators considered it appropriate to discuss the principle of clean hands in the three sections: (a) can a principle of clean hands or a legality requirement be read into the ECT?; (b) does the clean hands doctrine constitute a general principle of law?; (c) would any instances of the claimants' alleged "bad faith and illegal" conduct be caught by a legality requirement read into the ECT? Each of them will be dealt with below under the separate headings.

\subsection{THE PRINCIPLE OF CLEAN HANDS OR LEGALITY REQUUIREMENT AND THE ECT}

It has already been indicated that the question concerning the legality of investments and the related principle of clean hands has been discussed by investment tribunals in a number of cases ${ }^{44}$. For example, in Hamester, the Tribunal considered whether the conduct of the investor falls within the scope of investment protection granted under the Ghana-Germany BIT. It made a general observation that: "an investment will not be protected if it has been created in violation of national or international principles of good faith; by way of corruption, fraud, or deceitful conduct; or if its creation itself constitutes a misuse of the system of international investment

applicable rules and principles of international law". Article 31(1) of the VCLT provides that " $[\mathrm{a}]$ treaty shall be interpreted in good faith in accordance with the ordinary meaning to be given to the terms of the treaty in their context and in the light of its object and purpose".

43 Ibidem, at paras. 1345-1347.

44 See above, the quoted case law, supra note 28 . 
protection under the ICSID Convention. It will also not be protected if it is made in violation of the host State's law"45. Similarly, the Saur Tribunal stated that: "the finality of the investment arbitration system is to protect only lawful and bona fide investments. Whether or not the BIT between France and Argentina mentions the requirement that the investor act in conformity with domestic legislation does not constitute a relevant factor. The condition of not committing a serious violation of the legal order is a tacit condition, inherent to any BIT as, in any event, it is incomprehensible that a State offer the benefit of protection through arbitration if the investor, in order to obtain such protection, has acted contrary to the law" 46 .

In the context of the principle of clean hands and the ECT, the Plama Consortium Limited case seems to be of particular importance ${ }^{47}$. This case was discussed at length by the parties and the Tribunal itself devoted one paragraph highlighting thus its relevance to the present case ${ }^{48}$. The Plama Tribunal expressed the view that even though the ECT remains silent on the principle of clean hands, it did not mean that the protections provided for by the ECT cover all kinds of investments, including those contrary to domestic or international law. Having in mind the rules concerning the application and interpretation of treaties as well as the introductory note to the ECT which states that " $[\mathrm{t}]$ he fundamental aim of the Energy Charter Treaty is to strengthen the rule of law on energy issues" the Tribunal found that the ECT should be interpreted in a manner consistent with the aim of encouraging respect for the rule of law. Therefore, the Plama Tribunal concluded that "the substantive protections of the ECT cannot apply to investments that are made contrary to law" 49 .

As a consequence, the Tribunal, having previously established that the investment had been "the result of a deliberate concealment amounting

45 Gustav F W Hamester GmbH \& Co KG v. Republic of Ghana, Award of 18.06.2010, ICSID Case No. ARB/07/24, at para. 123.

46 SAUR International SA v. Republic of Argentina, Decision on Jurisdiction and Liability of 6.06.2012, ICSID Case No. ARB/04/4, at para. 308.

47 Plama Consortium Limited v. Republic of Bulgaria, Award of 27.08.2008, ICSID Case No. ARB/03/24.

48 Awards, at para. 1350.

49 Plama Consortium Limited v. Republic of Bulgaria, Award of 27.08.2008, ICSID Case No. ARB/03/24, at para. 139. 
to fraud, calculated to induce the Bulgarian authorities to authorize the transfer of shares" 50 and in the light of the ex turpi causa defence, could not lend its support to the Claimant's request and could not grant the substantive protections of the ECT ${ }^{51}$. It should be stressed that the Plama Tribunal considered and applied the ex turpi causa defence even though the ECT does not contain an explicit "investment made in accordance with law" clause. However, by employing the rules concerning the application and interpretation of the treaties the Tribunal came to the reasonable conclusion that despite the language of the ECT each investor has to abide by domestic and international law. Thus, it might be fairly concluded that the "investment made in accordance with law" clause is a general principle of international investment law which does not allow for granting legal protection to investments made contrary to law.

Thus, the Yukos Tribunal correctly noted that: "even where the applicable investment treaty does not contain an express requirement of compliance with host State laws (...), an investment that is made in breach of the laws of the host State may either: (a) not qualify as an investment, thus depriving the tribunal of jurisdiction; or (b) be refused the benefit of the substantive protections of the investment treaty" 52 . Consequently, the Tribunal held that an investment may not be protected, if it has been made in violation of host State's law or by an investor acting in bad faith. This principle exists independently of specific language in an investment treaty. These treaties impose obligations on States to treat investors in a fair and transparent fashion while at the same time they seek to encourage legal and bona fide investments ${ }^{53}$.

In response to the Respondent's argument that the right to invoke the ECT must be denied altogether to an investor in the case of illegality in the performance of an investment, the Tribunal found the argument unpersuasive and was of the view that the essence of the investment regime was to protect investors against host State actions, even when

\footnotetext{
50 Ibidem, at paras. 128-129, 134-135.

51 Ibidem, at para. 149.

52 Awards, at para. 1349

53 Ibidem, at paras. 1351-1352.
} 
this State deems an investor to have breached the law of the host State, because by virtue of this regime the investor may challenge the actions of States in accordance with an investment treaty. Accepting the Respondent's contention would amount to a priori deprivation of investment treaty protection granted to foreign investors. In the Tribunal's view: "[ $\mathrm{t}$ ]here is no compelling reason to deny altogether the right to invoke the ECT to any investor who has breached the law of the host State in the course of its investment. If the investor acts illegally, the host state can request it to correct its behavior and impose upon it sanctions available under domestic law, as the Russian Federation indeed purports to have done by reassessing taxes and imposing fines. However, if the investor believes these sanctions to be unjustified (...), it must have the possibility of challenging their validity in accordance with the applicable investment treaty. It would undermine the purpose and object of the ECT to deny the investor the right to make its case before an arbitral tribunal based on the same alleged violations the existence of which the investor seeks to dispute on the merits".

In addition, the Respondent could not cite any decision in support of its argument. According to the Yukos Tribunal, the statements of investment tribunals relied on by the Respondent were all made obiter and are too vague to allow any certain conclusions to be reached as to their intended meaning 54 . Having also that in mind, the Arbitral Tribunal decided that it would not read any legality requirement with respect to the conduct of the investment into the ECT. A contrario, it may seem that the Tribunal would read into the Treaty the legality requirement with respect to the making of the investment.

The Tribunal decision may be regarded in part as controversial. The Tribunal prudently noted that illegal or mala fide investment should not be allowed to benefit from investment protection. However, it further decided that in the case of performance of an investment the legality requirement cannot be read into the ECT and, thus, only explicit treaty language may exclude such investments from the investment protection. This part of the Tribunal's reasoning cannot be endorsed. As the Tribunal itself stated, investment treaties seek to encourage legal investments.

54 Ibidem, at para. 1356. 
If an investor has made its investment in accordance with the host State law, but then, subsequently, has breached that law and the State reacted by imposing upon it sanctions provided for in domestic law, it may be the case that the substantive treaty protection cannot apply to such an investment. Depending upon the circumstances of a given case, a tribunal should either deprive the investor of investment protection (e.g. breaches of fundamental human rights) or find that the host State has not breached any of substantive provisions of the BIT. Therefore, in the second alternative and as the Fraport Tribunal decided, the breach of the host State's law may be a defence to claimed substantive violations ${ }^{55}$.

\subsection{THE PRINCIPLE OF CLEAN HANDS AS A GENERAL PRINCIPLE OF LAW}

The Respondent argued that the principle of clean hands is a general principle of law within the meaning of Article 38(1)(c) of the ICJ Statute and, thus, because of the "unclean hands" of the investor, it bars an investor from making a claim before a tribunal. The Tribunal was not convinced by the argument and decided that the principle in question is not a general principle of law ${ }^{56}$. While the Tribunal's decision is correct, its reasoning remains to some extent doubtful and, to say the least, too concise and inconsistent.

The first controversy arises with the statement that "[g]eneral principles of law require a certain level of recognition and consensus" 57 . The Tribunal did not explain what level is required and used only the term "certain" which remains, in this context, vague and imprecise. Secondly, the Tribunal again did not explain who should recognize a general principle and whether the recognition should be given by "civilized nations" as provided for in Article 38. Thirdly, the Tribunal once more was esoteric when it spoke of "consensus". It did not point out who should express this consensus and whether the consensus as opposed to recognition, should be expressed by other subjects than civilized nations. Instead of shedding some light on the terms employed in its decision,

\footnotetext{
55 Fraport AG Frankfurt Airport Services Worldwide v. Republic of the Philippines, Award of 16.08.2007, ICSID Case No. ARB/03/25, at paras. 354, 395.

56 Awards, at para. 1358.

57 Ibidem, at para. 1359.
} 
the Tribunal decided to state that "there is a significant amount of controversy as to the existence of an «unclean hands» principle in international law". While it may be considered as a correct statement, it needs to be noted that the Tribunal itself created another controversy with respect to the general principles of law and the principle of clean hands by deciding not to make clear what are the reasons for rejecting the principle of clean hands as a general principle of law. In short, its reasoning remains disappointing and unsatisfactory. Such abstinence should disappoint those observers who might have expected some illuminating words on a rather controversial and much-discussed question of law at the present stage of development of international law.

The second controversy concerns the authorities referred to by the Tribunal. The Respondent demonstrated that "certain principles associated with the "clean hands» doctrine, such as exceptio non adimpleti contractus and ex iniuria ius non oritur have been endorsed by the PCIJ and the ICJ"58. It further relied on the separate opinion of Judge Simma which raises serious doubt as to the continuing existence of the exception in international law ${ }^{59}$. However, the Tribunal did not give any reasons whatsoever as to why the separate opinion should be followed 60 . The Respondent also relied, inter alia, on the dissenting opinion of Judge Schwebel, an arbitrator in the current arbitration, to conclude that the principle of clean hands forms part of international law. However, the Tribunal pointed out that: "[r]espondent has been unable to cite a single majority decision where an international court or arbitral tribunal has applied the principle of «unclean hands» [sic] in an inter-State or investor-State dispute and concluded that, as a principle of international law, it operated as a bar to a claim" 61 .

\footnotetext{
58 Ibidem, at para. 1360, referring to Individual Opinion by Mr. Hudson, Diversion of Water from the Meuse, Judgment of 27.06.1937, PCIJ Publ., Series A/B, No. 70, at 77; Gabčikovo-Nagymaros Project (Hungary/Slovakia), Judgment of 25.09.1997, I.C.J. Reports 1997, at para. 133.

59 Separate opinion of Judge Simma, Application of the Interim Accord of 13 September 1995 (the former Yugoslav Republic of Macedonia v. Greece), Judgment of 5.12.2011, at paras. 19-20.

60 Awards, at para. 1360.

61 Ibidem, at para. 1362.
} 
For the above reasons, the Tribunal concluded that the principle does not exist as a general principle of international law which would bar a claim by an investor, and the Claimants in the present case ${ }^{62}$.

First of all, the Tribunal could not discuss the associated principles, since they do not reflect the proper principle of clean hands. Second, the opinion of Judge Simma gives an excellent resume of the principle of reciprocity and exceptio non adimpleti contractus, but it still does not amount to be a persuasive authority in international law. A single and separate opinion cannot be regarded as a source of law which forms the basis of the Tribunal's decision. The Tribunal did not event deem it necessary to quote some of Judge Simma's arguments or develop its own reasoning. Such abstinence is again disappointing as it needs to be underlined that a court or tribunal should fully present reasons for a decision it delivers.

The third point refers to the opinion of Judge Schwebel. In the Nicaragua v. USA case, Judge Schwebel held that the Court should have rejected Nicaragua's claims because it did not go to the Court with clean hands. Therefore, the principle of clean hands should have been applied by the ICJ: “(...) as the aggressor, indirectly responsible - but ultimately responsible - for large numbers of deaths and widespread destruction in El Salvador apparently much exceeding that which Nicaragua has sustained, Nicaragua's hands are odiously unclean. Nicaragua has compounded its sins by misrepresenting them to the Court. Thus both on the grounds of its unlawful armed intervention in El Salvador, and its deliberately seeking to mislead the Court about the facts of that intervention through false testimony of it Ministers, Nicaragua's claims against the United States should fail" 63 .

According to Judge Schwebel, exceptio non adimpleti contractus is a general principle of law ${ }^{64}$. Judge Schwebel invoked, inter alia, the Claims of Clark and Daniels case ${ }^{65}$, Pelletier's case ${ }^{66}$, the opinions of Judges Hudson,

\footnotetext{
62 Ibidem, at para. 1363.

63 Dissenting Opinion of Judge Schwebel, supra note 34, at para. 268.

64 Ibidem, at para. 269.

65 Opinion of Mr. Hassaurek, Claims of Clark and Danels: Cases of "La Constancia", "Medea", and "Good Return". The Ecuadorian-United States Claims Commission, 8.09.1865,
} 
Anizlotti and Morozov67, the Diversion of Water from the Meuse case ${ }^{68}$, the Mavrommatis Jerusalem Concessions case ${ }^{69}$ and the Factory at Chorzów case $^{70}$. He also quoted well-known international lawyers, including B. Cheng and G. Fitzmaurice ${ }^{71}$. Judge Schwebel recalled especially the Diversion of Water from the Meuse case, and found that Nicaragua was similarly asking the Court to decree a kind of specific performance of a reciprocal obligation which it was not performing, and which the Court should have refused ${ }^{72}$. Judge Schwebel concluded that if Nicaragua was guilty of illegal conduct, its conduct: "(..) should have been reason enough for the Court to hold that Nicaragua had deprived itself of the necessary locus standi to complain of corresponding illegalities on the part of the United States, especially because, if these were illegalities, they were consequential on or were embarked upon in order to counter Nicaragua's own illegality - in short were provoked by it"73.

Judge Schwebel's dissenting opinion thus underlines both the reciprocal nature of the obligation held by Nicaragua, as well as its lack of standing to bring a claim. Judge showed a sort of judicial activism, since the United States had not itself invoked the doctrine as a ground

[in:] J.B. Moore, History and Digest of the International Arbitrations to Which the United States Has Been a Party, Washington: Government Printing Office 1898, vol. III, p. 2738-2739.

66 Pelletier's Case, 1885, Papers Relating to the Foreign Relations of the United States: The Executive Documents of the House of Representatives for the Second Session of the Forty-Ninth Congress, 1886-1887, Washington 1887, p. 607.

67 Individual Opinion by Mr. Hudson, supra note 58, at 77; Dissenting Opinion by M. Anzilotti, Legal Status of Eastern Greenland, Judgment of 5.04.1933, PCIJ Publ., Series A/B, No. 53, p. 95; Dissenting Opinion of Judge Morozov, United States Diplomatic and Consular Staff in Tehran (United States of America v. Iran), Judgment of 24.05.1980, I.C.J. Reports 1980, par. 3.

68 Diversion of Water from the Meuse, Judgment of 27.06.1937, PCIJ Publ., Series A/B, No. 70, p. 25. "[L]a Cour estime difficile d'admettre que les Pays-Bas soient fondés à critiquer aujourd'hui la construction et le fonctionnement d'une écluse dont eux-mêmes avaient antérieurement donné l'exemple".

69 Mavrommatis Jerusalem Concessions, Judgment of 25.03.1925, PCIJ Publ., Series A, No. 5, p. 50.

70 Factory at Chorzów (Claim for Indemnity) (Jurisdiction), Judgment of 26.07.1927, PCIJ Publ., Series A, No. 9, p. 31.

71 B. Cheng, General Principles of Law as Applied by International Courts and Tribunals, London: Stevens \& Sons Limited 1953, p. 155; G. Ftizmaurice, The General Principles of International Law, Recueil des cours (RCADI) 1957, vol. 92, p. 119.

72 Dissenting Opinion of Judge Schwebel, supra note 34, at para. 269.

73 Ibidem, para. 272. 
of inadmissibility at the jurisdiction and admissibility stage $\mathrm{e}^{74}$. Therefore, his opinion at this point was to some extent unexpected. However, it could have been expected that Judge Schwebel would follow his opinion in further cases and, especially, in the Yukos cases.

The Respondent followed a similar pattern of reasoning relying heavily on jurisprudence, dissenting opinions where the principle of clean hands was invoked 75 . However, Judge Schwebel made a volte-face and agreed with other two arbitrators that the principle of clean hands does not exists in international law. The present Award remains in contradiction with his dissenting opinion in Nicaragua $v$. USA. It is rather disappointing when a lawyer inexplicably changes his views in similar cases as it may put in question his reputation.

\subsection{WAS THE INVESTMENT MADE IN BAD FAITH OR CONTRARY TO THE LAWS OF THE RUSSIAN FEDERATION?}

The PCA Tribunal held that a claimant may be barred from seeking relief under the ECT if its investment was made in bad faith are in violation of domestic law ${ }^{76}$. Thus the legality of the investment in its performance was outside the scope of the Tribunal's purview, although it pointed out that "some of the instances of Claimants" «illegal or bad faith» conduct (...) could have an impact on the Tribunal's assessment of liability and damages"77. Having reviewed the position of the parties, the arbitrators agreed with the Respondent that an examination of the legality of the investment may not be limited "to verifying whether the last in a series of transactions leading up to the investment was in conformity with the law. The making of the investment will often consist

\footnotetext{
74 Military and Paramilitary Activities in and Against Nicaragua (Nicaragua v. United States of America), Jurisdiction and Admissibility, Judgment of 26.11.1984, I.C.J. Reports 1984, at paras. 86-103.

75 Awards, at paras. 1361-1362. And the Tribunal correctly opined that "despite what appears to have been an extensive review of jurisprudence, Respondent has not been able to cite a single majority decision where an international court or arbitral tribunal has applied the principle of «unclean hands» in an inter-State or investor-State dispute and concluded that, as a principle of international law, it operated as a bar to a claim", since indeed there has been no decision in which a court or tribunal referred to the principle of clean hands.

76 Ibidem, at para. 1364.

77 Ibidem, at para. 1374.
} 
of several consecutive acts and all of these must be legal and bona fide"78. However, the arbitrators had already established in its Interim Awards that the purchases of Yukos shares had been legal ${ }^{79}$. Therefore, the Tribunal concluded that the Respondents "unclean hands" argument failed as a preliminary objection ${ }^{80}$.

\subsection{THE PRINCIPLE OF CLEAN HANDS AND CONTRIBUTORY FAULT}

As noted, in the Tribunal's view, the breach of a host State's law may be a defence to claimed substantive violations ${ }^{81}$. It may exonerate or attenuate responsibility (l'atténuation ou l'exonération de la responsabilité) as well as exclude or reduce the obligation to pay reparation. Hence, the principle of clean hands, while not being a proper legal principle in international law, may be embodied in certain legal concepts. The principle finds its emanation in those concepts, a fine example of which is contributory fault. This was, indirectly, the argument of the Respondent contending that Claimants may not recover from the Russian Federation the fruits of their own wrongdoing since it did not establish that their loss had been caused by the Russian Federation's actions in violation of its obligations under the ECT ${ }^{82}$.

There are two Articles in ILC Articles on State Responsibility which deal with the question of contributory fault and which were quoted by the Tribunal. They provide as follows:

Article 31. Reparation

1. The responsible State is under an obligation to make full reparation for the injury caused by the internationally wrongful act.

2. Injury includes any damage, whether material or moral, caused

\footnotetext{
78 Ibidem, at para. 1369.

79 Yukos Universal Limited (Isle of Man) v. The Russian Federation,UNCITRAL, PCA Case No. AA 227, Interim Award of 30.11.2009, at para. 431; Hulley Enterprises Limited (Cyprus) v. The Russian Federation, UNCITRAL, PCA Case No. AA 226, Interim Award of 30.11.2009, at para. 430; Veteran Petroleum Limited (Cyprus) v. The Russian Federation, UNCITRAL, PCA Case No. AA 228; Interim Award of 30.11.2009, at para. 474.

80 Awards, at paras. 1370, 1373.

81 Fraport AG Frankfurt Airport Services Worldwide v. Republic of the Philippines, Award of 16.08.2007, ICSID Case No. ARB/03/25, at paras. 354, 395.

82 Awards, at paras. 1594-1595.
} 
by the internationally wrongful act of a State ${ }^{83}$.

Article 39. Contribution to the injury

In the determination of reparation, account shall be taken of the contribution to the injury by wilful or negligent action or omission of the injured State or any person or entity in relation to whom reparation is sought ${ }^{84}$.

The Tribunal observed, on the basis of the above provisions, that it must determine whether there was a sufficient causal link between a wilful or negligent act or omission of the Claimants and the loss the Claimants ultimately suffered at the hands of the Russian Federation through the destruction of Yukos. Only contribution that is material and significant will trigger a finding of contributory fault. The PCA Tribunal underlined that it had a wide margin of discretion in apportioning the fault ${ }^{85}$. Regrettably, it did not, however, explain why and to what extent it had a wide margin of estimation. Such a general statement prescribing for a court or tribunal a significant competence without any justification should not be welcomed.

The Tribunal reviewed the investment case law in order to reach three conclusions which informed and assisted its subsequent analysis of contributory fault. First, the legal concept of contributory fault must not be confused with the investor's duty to mitigate its losses ${ }^{86}$. Second, in certain cases the contributory fault of the investor, while it may have increased the loss which it sustained, was unrelated to the wrongdoing

83 The ILC Commentary to this Article includes the following: "[i]t is true that cases can occur where an identifiable element of injury can properly be allocated to one of several concurrently operating causes alone. But unless some part of the injury can be shown to be severable in causal terms from that attributed to the responsible State, the latter is held responsible for all the consequences, not being too remote, of its wrongful conduct".

84 The ILC Commentary to Article 39 states that: "Article 39 deals with the situation where damage has been caused by an internationally wrongful act of a State, which is accordingly responsible for the damage in accordance with Articles 1 and 28, but where the injured State, or the individual victim of the breach, has materially contributed to the damage by some wilful or negligent act or omission".

85 Awards, at paras. 1599-1600.

86 Ibidem, at para. 1603, referring to EDF International S.A. and Ors v. Argentine Republic, ICSID, ARB/03/23, Award of 11.06.2012, at para. 1301. See also: Middle East Cement Shipping and Handling Co. S.A. v. Arab Republic of Egypt, ICSID, ARB/99/6, Award of 12.04.2002; AIG Capital Partners, Inc and Anor v. Republic of Kazakhstan, ICSID, ARB/01/6, Award of 7.10.2003. 
of the State. The fault of the investor contributed to the losses which flowed from the wrongful act of the State ${ }^{87}$. Last, there have been certain decisions where the tribunals found that the victim contributed to the State's wrongdoing 88 .

As earlier stated, the Respondent alleged 28 instances of illegal and bad faith conduct of the Claimants. The Tribunal found four of them to be wilful or negligent conduct which must be considered as potentially constituting fault that may have contributed to the destruction of Yukos. There were the following:

1. Yukos' conduct in some of the low-tax regions,

2. Yukos' use of the Cyprus-Russia DTA,

3. Yukos' conduct in connection with the YNG auction, notably the procuring of a Temporary Restraining Order by a Texas court and the published threat of a "lifetime of litigation", and

4. Yukos' conduct in connection with its bankruptcy, notably the non-payment of the A Loan ${ }^{89}$.

Having reviewed those instances, the Tribunal came to a conclusion that there was a sufficient causal link between Yukos' abuse of the system in some of the low-tax regions and its demise which triggered a finding of contributory fault on the part of Yukos ${ }^{90}$. In the case of Yukos' use of the Cyprus-Russia DTA the Tribunal was of the opinion that such conduct was subsumed into and enlarged the abuse of low-tax regions ${ }^{91}$. The remaining two instances were recognized as not constituting contributory fault. Consequently, the Tribunal went on to decide on the extent of contributory fault on the part of the Claimants, to wit, "whether Claimants' and Yukos' tax avoidance arrangements in some of the low-tax regions, including their questionable use of the Cyprus-

\footnotetext{
87 Ibidem, at para. 1604, referring to MTD Equity Sdn. Bhd. and MTD Chile S.A. v. Republic of Chile, ICSID Case No. ARB/-1/07, Award of 25.05.2004, and Iurii Bogdanov, Agurdino-Invest Ltd. and Agurdino-Chimia JSC v. Republic of Moldova, SCC Rules, Award of 22.09.2005.

88 Ibidem, at para. 1605, referring to Antoine Goetz $\mathcal{E}$ Consorts et S.A. Affinage des Metaux v. Republique du Burundi, ICSID, ARB/01/2, Award of 21.06.2012, and Occidental Petroleum Corporation and Occidental Exploration and Production Company v. Republic of Ecuador, ICSID, ARB/06/111, Award of 5.10.2012.

89 Ibidem, at paras. 1607-1608.

90 Ibidem, at paras. 1610-1632.

91 Ibidem, at para. 1621.
} 
Russia DTA (...), contributed to their injury in a material and significant way"92. The Tribunal took also into consideration the subsequent disproportionate and tantamount to expropriation conduct of Russia of the Claimants' investment ${ }^{93}$. Having considered and weighed all the arguments, it found that, as a result of the material and significant misconduct by the Claimants and by Yukos, the Claimants contributed to the extent of $25 \%$ to the prejudice which they suffered. Thus, the resulting apportionment of contribution to the injury as between the Claimants and the Respondent, namely 25\% and 75\%, was regarded by Tribunal as fair and reasonable in the overall circumstances of the case ${ }^{94}$.

\section{COSTS}

Both US law firms representing parties in the present dispute collected tens of millions of dollars in billings. Shearman \& Sterling LLP, acting for the Claimants, ended up billing about USD 79,628,055 in fees and expenses for its representation. Shearman's lawyers charged hourly rates ranging from $\$ 235$ to $\$ 1,065$ and billed more than 130000 hours. Moreover, its costs included another USD 10,020,275,57 and GBP 1,066,462 in expert fees and expenses, including USD 7,370,493 million for Navigant, the damages expert for Yukos's shareholders ${ }^{95}$. According to the Claimants, these costs are "reasonable" taking into account the circumstances of the case ${ }^{96}$.

The Claimants noted that the Respondent should bear all the costs, since the Respondent was the unsuccessful party in the jurisdiction and admissibility phase and the Claimants should prevail at the merits stage ${ }^{97}$. According to the Claimants, the Tribunal should take into account the circumstances of the case, in particular, the obstructionist conduct of the Respondent vis-à-vis the investor before and during the arbitration, the parties' success in the arbitrations, their conduct during

\footnotetext{
92 Ibidem, at para. 1633.

93 Ibidem, at para. 1635.

94 Ibidem, at para. 1637.

95 Ibidem, at para. 1847.

96 Ibidem, at para. 1872.

97 Ibidem, at paras. $1838-1840$.
} 
the proceedings, and the actual measures of the Respondent which gave rise to the dispute ${ }^{98}$. Therefore, the Respondent should bear all of Claimants' costs of legal representation and assistance. The Russian Federation was represented by Cleary Gottlieb Steen \& Hamilton LLP and Baker Botts LLP. They submitted that they had incurred USD $27,000,000$ in legal costs, plus another USD 4,500,000 in experts' fees and expenses ${ }^{99}$. The Respondent contested the Claimants' costs submission, calling it "plainly excessive and unprecedented in its amount" that "raises serious questions of credibility" 100 .

The Tribunal noted that the ECT contains no provisions on the allocations of costs of arbitration. However, Articles 38 to 40 of the UNCITRAL Rules contain provisions with respect to the allocation of costs ${ }^{101}$. Article 38 states as follows: "[t]he arbitral tribunal shall fix the costs of arbitration in its award. The term "costs" includes only: (a) the fees of the arbitral tribunal to be stated separately as to each arbitrator and to be fixed by the tribunal itself in accordance with article 39; (b) the travel and other expenses incurred by the arbitrators; (c) the costs of expert advice and of other assistance required by the arbitral tribunal; (d) the travel and other expenses of witnesses to the extent such expenses are approved by the arbitral tribunal; (e) the costs for legal representation and assistance of the successful party if such costs were claimed during the arbitral proceedings, and only to the extent that the arbitral tribunal determines that the amount of such costs is reasonable; (f) any fees and expenses of the appointing authority as well as the expenses of the Secretary-General of the Permanent Court of Arbitration at The Hague".

Article 40 provides that: "1. Except as provided in paragraph 2, the costs of arbitration shall in principle be borne by the unsuccessful party. However, the arbitral tribunal may apportion each of such costs between the parties if it determines that apportionment is reasonable, taking into account the circumstances of the case. 2. With respect to the costs of legal representation and assistance referred to in Article 38, paragraph (e),

\footnotetext{
98 Ibidem, at paras. 1842-1846.

99 Ibidem, at para. 1856.

100 Ibidem, at para. 1857.

101 Arbitration Rules of the United Nations Commission on International Trade Law, 1976.
} 
the arbitral tribunal, taking into account the circumstances of the case, shall be free to determine which party shall bear such costs or may apportion such costs between the parties if it determines that apportionment is reasonable".

As regards the costs of arbitration pursuant to Article 40(1), the Tribunal observed that the costs are to be awarded to the successful party and against the unsuccessful party, unless the circumstances justify a different approach. Therefore, the Respondent was ordered to bear these costs ${ }^{102}$. Regarding the costs for legal representation and assistance pursuant to Article 40(2), the Tribunal ordered the Respondent to reimburse to Claimants USD $60,000,000$ as part of their costs, since it would be "fair and reasonable in the circumstances" of the case ${ }^{103}$. The Tribunal underlined that it had "unfettered discretion to fix and decide in what proportion the costs for legal representation and assistance shall be borne by the parties"104. The Claimants, as the successful party, should be awarded a significant portion of their costs. The portion should be reasonable ${ }^{105}$. In determining the reasonable portion the Tribunal took under consideration the following relevant factors:

- the egregious nature of many measures of Respondent which were in breach of the ECT ${ }^{106}$,

- the prayer for relief ${ }^{107}$,

- the limited assistance of Claimants' experts to the Tribunal in the determination of damages 108 ,

- the considerable and outstanding work of the lawyers. The Tribunal observed that the stakes were high and the parties attached significant importance to the arbitration. It was evidenced by: "[ $t]$ he thousands of pages of written pleadings and exhibits submitted by the Parties, the myriad requests for production of documents, the Tribunal's lengthy procedural orders, the ten

\footnotetext{
102 Awards, at paras. 1868-1869.

103 Ibidem, at para. 1887.

104 Ibidem, at para. 1875.

105 Ibidem, at para. 1876.

106 Ibidem, at para. 1886.

107 Ibidem, at para. 1877.

108 Ibidem, at para. 1884.
} 
days of hearings in The Hague in the fall of 2008 on Respondent's objections to jurisdiction and admissibility, the 21 days of Hearings on the Merits in The Hague in the fall of 2013 (...). The Parties litigated vigorously. Each Party was represented by eminent counsel. The quality of the written and oral pleadings was outstanding. Counsel of both Parties are commended for their high professionalism" 109 .

The Tribunal observed that in these circumstances it was unsurprising that the costs reflected very considerable work. However, it agreed with the Respondent the some of the fees of Claimants' experts were "plainly excessive"110. Having in mind the contributory fault of the Claimants, the Tribunal concluded that USD $60,000,000$ is approximately $75 \%$ of Claimants' total of the costs.

\section{CONCLUDING REMARKS}

The Tribunal ordered Russia to pay damages in excess of USD 50 billion to the former Yukos shareholders and said they would be entitled to interest if the amounts were not paid up by 15 January 2015 . It should be underlined that the Tribunal correctly noted that the principle of clean hands does not form a part of positive international law. Although the above reasoning of the Tribunal remains doubtful, its decision to find breaches of the ECT was correct as it confirmed that each State, including a powerful State, is responsible under international law for the violations of investment treaties. It may be reasonably expected that efforts to collect the Award will drag on for years. The Russian Federation, whose economy is on the brink of recession, denounced the award and said it would appeal against the ruling by the Dutch courts. In its view: "[i]nstead of an objective, impartial consideration of the case, the arbitration court ruled based on current developments and as a result adopted a politically biased decision"111. Therefore, the Russian Federation

\footnotetext{
109 Ibidem, at paras. 1879-1880.

110 Ibidem, at paras. 1881-1882.

111 Reuters, 28.07.2014, http://uk.reuters.com/article/2014/07/28/uk-russia-yukosidUKKBNOFX08M20140728 [last accessed: 10.10.2014].
} 
seems to be planning to challenge enforcement claims in the many national courts around the world where such proceedings would be certainly instituted by the Claimants. It remains to be seen whether the former Yukos shareholder will successfully collect the damages from the Respondent in the years to come. 
